\title{
Higher Education for Economic Progress in a Global Framework with Special Reference to Bangladesh
}

\author{
Muhammad Mahboob Ali ${ }^{1}$, Vichayanan Rattanawiboonsom ${ }^{2}$, Sudhir K. S. Yadav ${ }^{3}$ \\ ${ }^{1}$ Department of Business Administration, Faculty of Business and Economics, Daffodil International University, Dhaka, Bangladesh. \\ ${ }^{2}$ Department of Business Administration, Faculty of Business, Economics and Communications, Naresuan University, Phitsanulok, Thailand \\ ${ }^{3}$ Faculty of Commerce \& Business Administration, Meerut College, CCS University, Meerut, India
}

Email address:

pipulbd@gmail.com (M. M. Ali), vichayananr@nu.ac.th (V. Rattanawiboonsom), sudhiryadavmeerut@gmail.com (S. K. S. Yadav)

\section{To cite this article:}

Muhammad Mahboob Ali, Vichayanan Rattanawiboonsom, Sudhir K. S. Yadav. Higher Education for Economic Progress in a Global Framework with Special Reference to Bangladesh. Journal of World Economic Research. Special Issue: The Globalization and Economic Structure Changes. Vol. 4, No. 5-1, 2015, pp. 40-52. doi: 10.11648/j.jwer.s.2015040501.16

\begin{abstract}
Globally education is the important factor to access in the market driven force which changes economic benefits. Higher education is adding value in the process of economic advancement of a country. The study raised the question to examine the impact of higher education of Bangladesh in the process of raising economic productivity. This study also assesses the standard of higher education of Bangladesh and further evaluates impact of higher education on economic productivity of the country. An opinion poll was conducted. The study recommends that quality of education should be maintained and more investment in the higher education ought to be provided from the budgetary allocation. Bangladesh needs global education which should have international benchmark so that society can improve in efficient and effective manner. If return on invested capital in education becomes efficient and effective for adding value and creating corner stone which ultimately helps to attain competitive advantage. To ensure quality education, pedagogy should be designed in such a way that fulfillment of global as well as domestic needs are possible following the standard curricula with practical exposure and outcome based teaching and learning system.
\end{abstract}

Keywords: Higher Education, Economic Productivity, International Benchmark, Bloom's Taxonomy, Outcomes-based Teaching and Learning

\section{Introduction}

Higher education is one of the tools to add value in the economic progress of a country. Higher education is highly correlated to reinventing thinking beyond boundaries to Excel and knowledge based resource society. Education actually means transformation of a person into a good human being. They should not be used by the vested quarters to serve their interest. Moral principles and ethical behavior should be incorporated into our education system.

Investment on higher education creates corner stone through value innovation through working in an effective market mechanism. Schultz(1961) observed that the most distinctive feature of the economic system is the growth in human capital. Without proper human capital a nation cannot achieve social welfare. Higher education relates to reinvesting thinking beyond boundaries to excel. McMahon (1992) estimated among five largest OECD countries including USA where he found that there were strong complementary relationship between higher education and basic education. Virtually basic education is the stepping stone to become knowledgeable person in future.

In Bangladesh, only about 12 percent graduates can enter into higher education. More than 80 percent of these students are taking higher education in the National University of Bangladesh's affiliated colleges/institutes. Others are in the public and private universities. (http://siteresources.worldbank.org/EDUCATION/Resources/ 278200-1121703274255/

$1439264-$

1193249163062/Bangladesh_countrySummary.pdf.) .

However, quality of the students of national university of Bangladesh varies depending on the nature of the colleges or institutes. Quality of approved institutes /colleges under national university is not quite good and it is very difficult to control or assess quality as National University of Bangladesh already can not to perform it duties since its 
inception. Wadud(2013) argued that since its inception in 1992, the National University has been struggling to provide quality education and has largely failed to supervise as many as 2000 colleges and institutes across the country with more than a million students. ( http://www.dhakatribune.com/education/2013/aug/02/nufailing-ensure-quality-education-its-

inception\#sthash.Immb60kN.dpuf). In Bangladesh currently, thirty-seven public universities, eighty -five private universities and three international universities(though South Asian University is situated at India) are providing education (Source: UGC, Bangladesh).Currently, the per capita income in Bangladesh is USD 1,314 as per Bangladesh Bureau of Statistics(2015).

Quality education helps to achieve reinventing thinking beyond boundaries to achieve superior success. It has been coordinated at the place of work through perseverance, enthusiasm, interpersonal skill, adding the value, so that transformation of persons, groups, institutes with innovative ideas, thoughts, entrepreneurship and technological advancement can happen with the vertical and horizontal coordination of efficiency and effectiveness. In the continuous process of changing scenario, reinventing thinking beyond is needed to sustain in the long run. If knowledge seekers want to limit his/her knowledge within limited topics then it will be difficult to maximize output from the learning. This may create imbalance in the society and as a resultant factor, an adverse impact on national development may occur. Imaginary ideas can come into exact representation if one takes hard and stiff effort with sufficient stress and time management. Benchmarking should be set at a global standard and requires human capital to grow at a great extent. Bangladesh is trying to improve high quality education.

According to Ministry of Education, Bangladesh with the assistance of the World Bank, has undertaken a Higher Education Quality Enhancement Project (HEQEP). The project aims at improving the quality of teaching-learning and research capabilities of the tertiary education institutions through encouraging both innovation and accountability and by enhancing the technical and institutional capacity of the higher education sector. The University Grants Commission of Bangladesh (UGC, Bangladesh) is the implementing agency of the project. A HEQEP Unit has been established in UGC for implementation, management, monitoring and evaluation of the activities (www.heqep-ugc.gov.bd).

To create human capital, expenditure on education should be raised. World Bank (2014) observed that tertiary education faces many deep-rooted and intertwined challenges. Bangladesh apportioned about $2.1 \%$ of its GDP to education, but just $0.12 \%$ was allocated to tertiary education - a very low share by any standards. Low levels of funding leaves little money for investing in research, labs, equipment, computers, books or electronic journals, and infrastructure maintenance for improvement of teaching, learning and research. World Bank's(2014) observation raised a question to examine the impact of higher education of the country in the process of raising economic productivity? QS University Rankings: Asia 2015 shows that among 100 universities in their list there is no university of Bangladesh. Ranking of University of Dhaka is 126 and Bangladesh University of Engineering and Technology is in between 201-250.In the list National University of Singapore's ranking is 1 in the year 2015(http://www.topuniversities.com/universityrankings/asian-university-

rankings $/ 2015 \#$ sorting $=$ rank + region $=+$ country $=+$ faculty $=+$ st ars $=$ false + search $=$ ).

Coffey(access date: 11 March,2015) described that the original Bloom's Taxonomy contained six developmental categories: knowledge, comprehension, application, analysis, synthesis, and evaluation. The first step in the taxonomy focused on knowledge acquisition and at this level, students recall, memorize, list, and repeat information. In the second tier, students classify, describe, discuss, identify, and explain information. Next, students demonstrate, interpret, and write about what they've learned and solve problems. In the subsequent step, students compare, contrast, distinguish, and examine what they've learned with other information, and they have the opportunity to question and test this knowledge. Then students argue, defend, support, and evaluate their opinion on this information. Finally, in the original model of Bloom's Taxonomy, students create a new project, product, or point of view (http://www.learnnc.org/lp/pages/4719).

India is now gaining third economic power of the world. Indian Institute of Science (IISc) Bangalore stood 34 and Mahidol University of Thailand stood 44 among top 300 universities of top Asian universities in the year 2015. (http://www.topuniversities.com/university-rankings/asianuniversity-

rankings $/ 2015 \#$ sorting $=$ rank + region $=+$ country $=+$ faculty $=+$ st ars $=$ false + search $=$ ).As neighboring countries, we are considering Indian higher educational system. Indian higher education system is facing an unprecedented transformation in the coming decade. This transformation is being driven by economic and demographic change: by 2020, India will be the world's third largest economy, with a correspondingly rapid growth in the size of its middle classes. Currently, over $50 \%$ of India's population is under 25 years old; by 2020 India will outpace China as the country with the largest tertiary-age population.

Despite significant progress over the last ten years, Indian higher education is faced with four broad challenges:

- The supply-demand gap: India has a low rate of enrolment in higher education, at only $18 \%$, compared with $26 \%$ in China and $36 \%$ in Brazil. There is enormous unmet demand for higher education. By 2020, the Indian government aims to achieve $30 \%$ gross enrolment, which will mean providing 40 million university places, an increase of 14 million in six years.

- The low quality of teaching and learning: The system is beset by issues of quality in many of its institutions: a chronic shortage of faculty, poor quality teaching, outdated and rigid curricula and pedagogy, lack of accountability and quality assurance and separation of 
research and teaching.

- Constraints on research capacity and innovation: With a very low level of $\mathrm{PhD}$ enrolment, India does not have enough high quality researchers; there are few opportunities for interdisciplinary and multidisciplinary working, lack of early stage research experience; a weak ecosystem for innovation, and low levels of industry engagement.

- Uneven growth and access to opportunity: Socially, India remains highly divided; access to higher education is uneven with multidimensional inequalities in enrolment across population groups and geographies.

The three central pillars of the government's plans for education reflect these realities: expansion, equity and excellence. Over the next five years, every aspect of higher education is being reorganized and remodeled: funding, leadership and management, quality assurance, accountability, relationships with industry, international collaboration and the way teaching and research are conducted. Emphasis will be placed on strengthening existing institutions. In arguably the biggest reform in the governance and funding of state universities, an ambitious programme is underway to devolve authority and budgets for higher education from federal government to the state governments.

The private sector, which currently accounts for $59 \%$ of all tertiary enrolment, continues to grow rapidly, providing most of the professional courses, particularly engineering and management. Many more providers are waiting for legislation which would allow them to enter the market. The private sector is expected to play a significant role in the future expansion of higher education in India.

\section{Literature Review}

Psacharopoulos (1994) argued that the investment in education continues to be a very attractive investment opportunity in the world today - both from the private and the social point of view.

Brownand Lauder(1996) argued that a polarized society will not create high standards of educational achievement for all. They established a framework for reconciling the aims of equality of opportunity with economic prosperity under the present global economic conditions.

Blundell,Dearden,Meghir and Sianesi (1999) observed that there is a substantial body of evidence on the contribution of education to economic growth.

Heckman (1999) observed that the returns to human capital investments are greatest for the young for two reasons: (1) younger persons have a longer horizon over which to recoup the fruits of their investments; and (2) skill begets skill.

Olssen and Peters (2005) commented that in a global neoliberal environment, the role of higher education for the economy is seen by governments as having greater importance to the extent that higher education has become the new star ship in the policy fleet for governments around the world. The recognition of economic importance of higher education and the necessity for economic viability has been initiated to promote greater entrepreneurial skills as well as the development of new performance measures to enhance output and to achieve targets.

Hanushek and Woessmann (2007) found that there is an importance of both minimal and high-level skills, the complementarily skills and the quality of economic institutions, and the robustness of the relationship between skills and growth. International comparisons incorporating expanded data on cognitive skills reveal much larger skill deficits in developing countries than generally derived from just school enrolment and attainment. The magnitude of change needed to make it clear that closing the economic gap with industrial countries will require major structural changes in schooling institutions.

Dukkipati's (2010) contention that skill/knowledge has spurred economic growth in India is perhaps the most important line of reasoning in this discussion. The author argues that unlike China and the -Asian Tigers, India's economic growth has not been impelled by manufacturing; instead, it is the skilled workforce that has allowed India to step up on the economic ladder speedily. The author cites ICRIER to report that India boasts the world's largest pool of techno-engineering talent; while India generates 400,000 engineers each year, the US only 60,000 ! The crux of the author's argument is that to continue with this upward trend-at the very least to sustain the current growth rate, the country's Gross Enrolment Ratio (GER) would have to increase from 12 to 20 percent by 2014 .

As impressive as the phenomenal growth of higher education in India is, more concerted efforts are required to keep the momentum going.

According to ICRIER, in 1950, India had 263,000 students enrolled in 750 colleges, which were affiliated with 30 universities. By 2005, the numbers had grown dramatically: 11 million students in 17,000 colleges affiliated with 230 universities. Another 10 million students were enrolled in 6,500 vocational institutions. Despite this phenomenal growth, India would have to nearly quadruple existing college seats and more than quadruple the number of professors to achieve the 20 percent GER by 2014 cited in the Venture Intelligence Reportl (Dukkipati, 2010).

Dukkipati (2010) contends that the irrefutable association between research and higher education has been ignored by the Indian Government. The author illustrates the case with stark statistics: -only 4 percent of research expenditure is made through universities. In the United States the corresponding figure is 17 percent and in Germany it is 23 percent. Moreover, India's higher education institutions are poorly connected to research centers. China's investment in research manpower, estimated at 708 researchers per 1 million people, is six times that of India'sll.

Malan(2010) described that if outcomes-based education (OBE) survives, the academic quality of the first entrants of the OBE cohort into the workplace and higher education sectors will not only reveal the assumed benefits and values of OBE, but its shortcomings as well. 
De Meyer (2012) offered that some reflections on what to see as the challenges of implementation and how one can overcome globalization of management education; focusing in particular on the need to understand what the driver for the globalization is and on implementation issues, e.g. how to build an international brand, some of the lessons one can learn from professional firms about the internationalization of key staff, the impact on the business model of a University, and the need for internationalization of the school's leadership and the deployment of technology. This work suggested that a good preparation requires that one should clarify the drivers for innovation and adjust the organizations and their management to this or these drivers. He suggested that in particular for brand building, preparation of the faculty and the leadership team, the deployment of technology, the adjustment of the business model, significant investments and changes will have to be made.

Gupta \& Gupta (2012) uphold Dukkipati's(2010) contention about the Government's desertion of research. The authors record that the Government expenditure on research and development in science and technology as percentage of GDP was $0.8 \%$ during 2005-06 in India. By way of comparison, the equivalent figure for Israel was $5 \%$, Sweden (4\%), Japan (3\%), US (2.77) and China (1.5\%).

Monem and Baniamin (2010) argued that the strategic plan document for higher education suggests that in the face of a changed scenario of higher education, quality improvement in the higher education has to be the main focus of attention and development of science and technology based education should be given top priority by the government and the private sector in the next two decades.

Mazumder (2012) commented that we must consider higher education as a critical investment towards the future of our nation to be competitive in the global marketplace.

Ahmmed(2013) found that session jam is currently one of the most alarming situations prevailing in the universities in Bangladesh. It is hindering the higher education in Bangladesh.

Alam(2013) depicted that the interface between industry and university (especially private ones) should be made regular and strengthened; involvement of industry personnel in course-curriculum development and transaction will help close the gap between the two vital sectors of the economy.

Clark (2013) comments that reinvention and overcoming past perceptions can be a daunting process. She also observes that sometimes, one's reinvention is by choice a creative embrace of a new direction. Her observations are based on facts as in attendance of an unrestraint with amid source of deliberations towards its renovation procedure which should be dedicated on amazing practical scenario so as to exclusively characterize by aptitude of innovative ideas, willingness, risk taking aptitudes, competencies, abilities and thoughts. Visionary zeal and Missionary activities may lead to pursue for attaining competitive advantage with superiority so that business environment can grow and put positive impact lead to higher growth of gross domestic product.
Sarkar, Rana and Zitu (2013) found that quality in higher education is a much debated issue in Bangladesh nowadays. Comparatively, newly established general universities are suffering more due to low budgetary support than the older technical universities. Bangladesh as a developing country needs to develop and ensure minimum facilities for quality higher education in all the public universities without discrimination. If Bangladesh could successfully address the existing challenges of quality higher education and ensure essential facilities for the same through budgetary provision, it could provide world class higher education at moderate cost and it could be an example to the whole world.

$\mathrm{Wu}$ and Haak (2013) stated that an important method of enhancing or developing new corporate differentiating emerging technological competences is to establish corporate central R\&D. This practice is centered on the competencybased view of the firm and has been implemented by companies in numerous developed countries.

Khaled (2014) observed that in Bangladesh, at the academic level teachers use rote memorization of text materials for students' knowledge or learning, instead of facilitating them to use brains how to think, understand, communicate, apply knowledge and solve real-life or workplace problems. There is not enough environmental instruction and assessment-wise accommodation for students having special needs. Giving extra time to slow learners for homework, quiz, test and examinations may be cited here as example. Students are not looked after, according to their individual ability, need and interest by most of the teachers at all levels of education as they are intimidated or abused emotionally and physically to learn, instead of motivating them by differential instructions of teaching and learning for delivery of lesson plans, assessment, evaluation and reporting by any local jurisdiction curriculum guideline.

Siddiqi (2014) depicted that higher education should be promoted and provided in such a way as to achieve the required level of economic development. To provide higher education in a planned way, the country needs to prepare national manpower plans. Therefore, Bangladesh's Five Year Plans should contain a separate chapter on national manpower planning matching various targets of economic development. Higher education needs to be given higher priority than it has received in the past in national development plan.

Williams (2014) shows that there is a definite connection between education and economic development. The five major themes found in the data are that 1) there is a connection between education and economic development, 2) education is used as a tool for economic development, 3) there are challenges to strengthening the relationship between education and economic development, 4) steps can be taken to increase this relationship, and 5) Hattiesburg has "all the right ingredients" to tap into this alliance.

Weiner, Jackman, and Warren (2014) said that Information literacy is the "equity in education" equalizer i.e., integrate and mainstream information literacy practice throughout formal and informal educational and workforce 
infrastructures.

Oplatka (2014) found that self-starter teachers engage in simple forms of innovative work behaviors (e.g., developing new curricula and teaching methods, initiating and implementing new projects, including school events). Additionally, the teacher's decision to go the extra-mile and initiate new projects or devise new curricula is related, though, to four major determinants, two of them external (e.g., the principal, the local education authority) and two internal (personal experiences, educational calling and emotional commitment).The self-starter teachers reported developing new curricula and teaching methods in road safety education to make it more suitable for the particular characteristics of their students and indicated initiating and implementing new projects (including school events) in the school or the class. Subsequent research should begin to inquire into how teachers bring out their new ideas, create new projects and suggest new instructional directions.

From the aforesaid literature review, we observed that there is a research gap in the field of measuring standard of higher education in Bangladesh as well as impact on the economic productivity of the county.

\section{Objectives of the Study}

Objectives have been taken as follows:

i) To assess current standard of higher education of Bangladesh;

ii) To evaluate impact of higher education on economic productivity of Bangladesh;

iii) To provide some implications of the study.

\section{Methodology of the Study}

In search of aforesaid objectives of the study, an opinion survey was conducted in following cities of BangladeshDhaka, Comilla, Chittagong, Sylhet, Rajshahi, Barisal, Khulna and Rangpur. Random sampling technique was applied and time period of the study is 1st January, 2014 to 31 st August, 2014.

Total number of questionnaires was distributed among 1600 person out of whom 1203 questionnaires were received. Among the respondents the study has chosen medical students, engineering students, agriculture university students of both public and private educational institutes, teachers from above types of institutes, guardians of existing students, bankers of public and private sectors, journalists ,politicians both present govt. supporter and opposition party supporter of the parliament. In the category of others respondents we have taken sample form Lawyers, agricultural scientists, job seekers, industrialists, women entrepreneur, non- resident Bangladeshis and business men. However, from received questionnaires, 89 questionnaires were not duly filled up for which these were rejected. Remaining questionnaires are valid and the results of these 1114 questionnaire as well as some other relevant information are duly reported. Among the respondents', those who are guardians in various capacities for them we kept scope for answering a comment in the questionnaire, which will be reported in the Section: 8.The study will also do the reliability test.

\section{Limitations of the Study}

The study mainly concentrates on Bangladeshi Higher Education System. However, the study does not consider quality of the students of National University for which they and their guardians are not included in the opinion pool survey. This is due to the fact that to do extensive research, it will need more time and will involve huge costs. Outcomesbased teaching and learning system was not extensively evaluated in the present study. Time and fund constraints are important reasons for not expanding the research work.

\section{Present Status}

Knowledge and research based education is a determining factor in a country like Bangladesh. Dissemination of knowledge can create high core competencies and maintain international benchmarking. Bangladesh should ensure knowledge and research based education especially at higher level of studies. Still University of Dhaka and Bangladesh University of Engineering and Technology (BUET) are proving their excellence as educational institutes. University of Chittagong is also better for contributing in the society. Jahangirnagar University and University of Rajshahi are also glowing. Some private universities have also proved their good education process. However, some so called self declared good education providing private universities of Bangladesh do not accept higher degrees especially $\mathrm{PhD}$ from public universities of Bangladesh. This is true but indicates mistrust about country's own educational system. Irony is that though Bangladesh doesn't lack appropriate knowledgeable person but only a few are interested in doing research work. Furthermore, Ministry of Education and UGC of Bangladesh do not give permission to the private universities to provide MPhil / PhD and DBA degree. Though work load of UGC of Bangladesh has raised but numbers of staff are not sufficient to supervise, monitor or implement higher quality education properly.

To become efficient and effective academician with synergy for educational institutes, professionals in this universe need to see solid realities of the society. Teachers are role model to their students. Honesty and sincerity of the teachers are very much important. They should act in response to the diverse issues of multi-cultural capabilities and principles. They ought to keep pace for achieving excellence of pursuit despite the fact that distance prevails between those who are the service providers and who are receiving service at the end. This gap can be narrowed down though arranging proper distribution channel of learning. Education quality should be ensured through doing international standard of research work and dissemination of knowledge without hindrance. This will help to accumulate, allocate and distribute knowledge in the global perspective. The axiom of the 
educational institute should pursue knowledge and do research works to safe guard the interest of the policy makers, fulfill need of the industry, entrepreneurs, business community and civil society. Environmental scanning of the educational institute will work as a communicative hub among the world of business community and technology prone people in the global perspective. As such students must refrain from national politics but they may do student politics for welfare of their own. This will help to meet the demand of the current domestic and global turbulent situation through strengthening quality assurance and capacity building of the organizations of both domestic and international arena. However, in Bangladesh, it is unfortunate that in some universities terrorist politics also prevailing, which must be stopped.

To attain knowledge based education not only private or public universities are sufficient. We need high quality branches of top world ranking educational institutes in Bangladesh through cross border arrangement. Earlier in this country Victoria University, Australia had a campus which was also providing high quality education. But previous government did not allow them to run the educational institute with some low graded institutes. Currently, Monash University of Australia is trying to launch a pathway program in Bangladesh which is a good imitative. But we should be more cautious regarding low graded /fraud universities who want to open branches in Bangladesh.

There is a battle taking place between India and China not for today's economic growth, but for economic growth a decade from now. The field of battle is higher education, and India is losing.

Higher education enrollment is a foremost indicator of economic growth. When a country substantially increases the number of university students it educates, that country tends to enjoy a spike in economic growth in the decade that follows. It happened with Japan and Korea in the early and late 1980 s respectively.

China will soon reap the rewards of its annual \$250-billion investments in higher education. Since the turn of the millennium, China has doubled the number of institutes of higher education and increased enrollment five-fold. It has been the greatest expansion in university education in the history of mankind.

As a result, $26 \%$ of China's university-age population is enrolled in an institution of higher education, versus $18 \%$ in India. It was not always so. In 1990 and 2000, India bested China in university enrollment rates. Until China decided to make higher education a policy priority, it will be difficult for them to keep their country in the right track.

Do not let India's outliers - the IITs and IIMs - fool you. The key battlefield is in higher education for the masses. And on this China wins hands down, on both quality and quantity. Sure, India's IITs and IIMs offer top-notch education. But they reach a scandalously small proportion of Indian students.

The annual intake of the IITs currently amounts to about 10,000 students, a fraction of India's 12-crore-strong university-going population.
So what is India doing to catch up? Not much. The University Grants Commission's 12th Five Year Plan (covering 2012-2017) is short on ambition and long on vague laments ("considerable challenges remain" it says). While China has ambitious plans that it executes, India has unambitious plans that it fails to execute.

In 1995 the Indian government introduced in parliament a bill to allow foreign universities to operate in the country. The Foreign Education Providers Bill, a successor to the 1995 bill, is still languishing in parliament nearly two decades later.

With India incapable of rapidly building higher-education infrastructure, and stubbornly refusing to let foreign universities in to help, the situation would be hopeless but for one fact: technology is coming to India's rescue. American universities, led by Harvard and MIT, have decided to put their courses online for free.

Any Indian with access to a computer and an internet connection (whether in his home or in the next village) can take a class taught by a Nobel laureate in Boston or Princeton or Berkeley. Some 200 American universities are interested in joining the Harvard/MIT not-for-profit venture.

The implications of free online content for Indian higher education - and for India's future economic growth cannot be overstated. This revolution knocks down in a single blow the historical barriers to Indian higher education: uneven quality, overall lack of supply, and the high cost of sending a child overseas for study.

The availability of free online content will lead to an entirely new model for higher education in India. Forget the sprawling university campus with faculty developing their own course content. Now is the time for India to invest in a new higher-education model built around content in-sourced from top North-American institutions?

No one can pretend that free online content is a panacea for India's education woes. There are countless other shortcomings in the Indian system, including insufficient preparation for university studies beginning at primary school and through to secondary.

Vocational training (for those better suited to learning a trade than attending university) is another huge gap. And outside of the urban elite of Tier 1 cities, English-language skills among university-age Indians are limited, as is access to the internet.

Despite these complex challenges, the new reality of this revolution is quite simple. The demand in India is there. So is the brainpower. And the content is now available for free. The only thing required is a system to connect the content with the students.

Can real-time translation technologies be used to convert Harvard's classes into Hindi, Telugu or Malayalam? Will the new model be solely distance learning, or will students come together to discuss the material? Can existing village school facilities be leveraged after school hours?

In China, India, and Malaysia there are various branches of quality full foreign educational universities/institutes. It is unfortunate that some profit makers in the educational sector 
in the name of study centre are doing misconduct. But for them we should not stop foreign branches of high quality educational institutes. Similar types of offences are being done by some private universities and medical colleges as reported by different dailies. UGC of Bangladesh may take appropriate measures so that cross border quality education institute branches can run in Bangladesh. UGC may address the issue of cross border education so that there is opportunity of education in quality education institutes for higher education in Bangladesh while those who are working as a study centre and not maintaining the quality will have to be driven out. Parameters must be set upon course curriculum meeting global and national need, number of $\mathrm{PhD}$ faculties, research works, publications, interactive class rooms, peer reviewed journals, regular seminars, workshops, conferences, symposiums, using Google class room, Business incubator for studying business, books/journals in the library, appropriate technological use as a tool to take classes, cultural and co-curricular activities. Strong measures ought to be taken against those who are doing false business in the name of providing higher studies such as involvement of any private university or fake study centre.

Currently standard of some private universities is very low which were mainly established by so called businessmen for making profit only. Irony is that some private university possesses land more than one acre and they do not have good quality faculties. There should be a rule that each year at least two research based articles of a faculty must be published in peer reviewed journal. Many faculties in Bangladesh think that they have already finished education so why they should do further research. This sort of perception can be changed if UGC made compulsory rule for publication of research based articles. When more research work will be emphasized then quality education will be feasible.

Innovation along with proper research techniques, managerial skills and applicability of information and communication technology will lead to transformation of excellence. Modernization can enhance managerial skill and better access to the information which provides an opportunity to explore the idea of originality. Innovative themes will help to gather knowledge in the area of achieving new products and services, fresh schemes of invention, opportunity for latest market scenario, original foundation of delivery, and dazzling performance of classification through brain storming. As such education institutes ought to put emphasis on innovation in quality education. Quality education may be very much constructive for thought provoking ideas, penetrating knowledge management, uniqueness and spread of information and communication technology. Process layout and designing of education should be done in such a manner that rejuvenation will work as a creativity to exemplify a dimensional assembling processes, superb distinct with the extent of deep-seated driving forces will fetch benefits for the participants as well as regional and global leaders and assist to formulate and implement strategies with extra zeal and passion. Knowledge diffusion will craft avenues to develop skills.
Present government may be thanked for their recent decision to give permission to open new private universities. Hope that in each district at least one public university should be set up. Side by side good colleges like Chittagong Government College, Dhaka College, Comilla Victoria College, B.L. College ,Khulna, Eden Girls' College etc. may be considered to make full fledged universities. In a country where population is more that 16.8 crore we need more universities. Further we need high quality cross border educational institutes branches in Bangladesh. UGC can compulsorily ask for the faculties to do research work as a mandatory and at least two articles in a peer reviewed journal may be published by each academician in each year. Standard of the institutes/colleges under National University is very low. As such present government may set up an inquiry commission to find out how to improve the quality education of the institutes /universities. Expenditure on higher education must be raised by the government. Also philanthropists should come forward to provide donations to public universities. Syllabus should be international standard and suitable to the needs of the industry and class room atmosphere should be improved. Cross border higher education regulations should be prepared by the Ministry of Education of Bangladesh and a special bill may be placed in the National assembly. More than six years education minister of the country tried to develop higher education system of the country. But without top ranking global institutes, international standard higher education is not properly feasible for which special steps are required by the government. New incremental innovations or changes to the education may allow enlargement to carry on efficiently and effectively transformation of core competent human capital and as a result return on investment on education sector will be positive.

Educational business in the money centric society can characteristically make distant mode of more technological innovations which can perhaps hope to fetch to souk through which successfully for reinventing thinking beyond boundaries with excel. There is a need for planned organizational harmony and procedure to handle innovation from thoughts phase to commercialization keeping the profit level at a normal profit. Political unrest, violence against women, immorality, leakage of question, unethical behavior, some banks unlawful profit gain through taking higher spread between interest rate on deposit and interest rate on advance, manipulation in the capital market, labor grievance, communalism, non-compliance of law and global attitudes towards countries like Bangladesh is a deep rooted problem. Dead weight loss cannot be permitted to work in the process. Moving forward is the way for receiving a goal oriented results at a boundary less world with diversified products and services supported by human capital since scared to make the require devoted jeopardy of really allowing latent can be reached through continuous process of strategic alliances among the partners not only domestically but regionally and globally. This may lead to achieve corner stone though capacity building with creation of new market space in 
different parts of the world. Through edge of boarders just about budding by no means in actuality, search out an accurate counter at the same time as to if that imminent was taken an advantage often or if we very soon blow creative obstacles through knowledge diffusion. Rather social welfare should be accompanied by social justice and income equality for betterment of the individual, team spirit, organizations, society and the nation as a whole. Kaldor-Hicks's compensation principle (https://en.wikipedia.org/wiki/Kaldor\%E2\%80\%93Hicks eff iciency ,access date :15 May,2015) with the spread of quality education at higher studies may help to attain some changes in the economy which shifts the individuals from a situation on a lower utility possibility curve to a situation on a higher utility possibility curve that will increase social welfare. But policy makers of the country should be cautious that higher studies are highly linked from the primary level to mid level, and then to high school degree. As such each stages of the education should maintain standard education.

But some private universities are failing to impart quality education. Moreover, medical education in the private sector also varies depending on the nature of an institute. Some medical colleges in the private sector is openly doing business. To ensure quality education, course curricula should be designed in such a way that fulfillment of global as well as domestic needs are possible following the curricula. Alumnus of the universities and current students' feedback of the university is very much important. Further, from the point of view of the employers', their scaling about the university to give scope for employment of the young learners' is important. Proper assessment of supply and demand in the employment opportunity will help the society in attaining young learners in entering job market.

The world of education contends with many new, dynamic and powerful influences. Organizations are faced with a rapidly globalizing economy, volatile economic markets, technological innovations, a greater emphasis on quality environmental and social responsibility, and an internationally spread workforce. The world of the current times, therefore, demands that managers possess a broadened cultural understanding and perspective and decision-making skills which may extend beyond the domestic and traditional area. The need for global education should no longer be regarded as optional; it should become mandatory.

IBA of the University of Dhaka is offering relatively quality education in the area of Business. Besides IBA, business faculties of well established public universities are imparting good education. Some private universities are also maintaining a good standard in imparting quality education. A good number of students are studying business. Quality of education at the higher level of our country varies from one university to another. Some public universities are giving good education. But some of them lack good faculties as well as good teaching atmospheres. Similarly, only a few private universities are relatively good. These include North South University, University of Liberal Arts of Bangladesh, American International university of Bangladesh, Daffodil
International University, United International University, East West University, Independent University of Bangladesh, and BRAC University.

The government should allow cross-border educational institutes in Bangladesh. More emphasis should be given on setting up high quality cross-border educational institutes having Under Graduation Honors, Masters, PhD and Post doctoral courses. Same thing should be done in medical science area as well under the joint venture with the USA, Australia, Canada, and the UK specially. Accreditation council may be set up to ensure higher education at different universities in Bangladesh. To ensure quality education, UGC may stress the need for more research work by teachers and young learners. For instance if we talk about study on Economics, we shall observe that economics is a subject that aims to ensure welfare of the society and human being. Therefore, more emphasis should be laid on the need of society as well as social welfare. But the syllabus of Economics should be reviewed and redesigned from the perspective of social obligations. An average young learner is now scared to study Economics. Behind this, main reason is in the syllabus more emphasis is given on mathematics at Honors and Masters Degree level.

Young learners' of Bangladesh are our future leaders and success of the country depends on them. They are very energetic, courageous, innovative and enthusiastic and possess zeal to serve the country. If they get proper education and scope for learning, they will be able to guide the country in proper direction in the future.

\section{Analysis of Opinion Survey}

On the basis of opinion pull survey we are summarizing the results of the findings:

Table 1. Impression about the recent steps on Higher education: (In percentage).

\begin{tabular}{lll}
\hline Type & Positive & Negative \\
\hline Students & 393 & 141 \\
Guardians & 103 & 19 \\
Academicians & 133 & 24 \\
Bankers & 54 & 27 \\
Journalists & 46 & 22 \\
Politicians & 54 & 21 \\
Others & 62 & 15 \\
\hline
\end{tabular}

(Source: Opinion Survey)

Inference: Most of the respondents opined that positive impacts are seen on account of recent steps have been taken by Bangladesh Government in the area of higher education.

Table2. Reliability Statistics.

\begin{tabular}{ll}
\hline Now we observed following reliability test result. \\
\hline Cronbach's Alpha & N of Items \\
\hline .767 & 2 \\
\hline
\end{tabular}

(Source: Estimated) 
Inference: From Table 2, the study observed that the indicates relatively high internal consistency. reliability coefficient is 0.767 , which is acceptable as it

Table 3. Positive Impact on Bangladesh Economy due to spread of Higher Education.

\begin{tabular}{llllll}
\hline Type & Strongly Agreed & Moderately Agreed & Neutral & Moderately Disagreed & Strongly Disagreed \\
\hline Quality Education & $25 \%$ & $25 \%$ & $21 \%$ & $9 \%$ & $20 \%$ \\
Accessibility of Education & $42 \%$ & $15 \%$ & $10 \%$ & $8 \%$ & $25 \%$ \\
Governmental help is sufficient & $27 \%$ & $14 \%$ & $18 \%$ & $16 \%$ & $25 \%$ \\
Proper monitoring by UGC & $18 \%$ & $11 \%$ & $15 \%$ & $32 \%$ & $24 \%$ \\
Industry Need based education & $12 \%$ & $24 \%$ & $17 \%$ & $21 \%$ & $26 \%$ \\
\hline
\end{tabular}

Source: ibid

Inference: From Table 3 when asked about the quality education imparted in Bangladesh, 25\% strongly agreed, 25\% moderately agreed, and $21 \%$ were neutral. On the contrary, $20 \%$ people were strongly disagreed. They are in opinion that the quality of education in Bangladesh is not good. When we asked about the accessibility of education to the common people $42 \%$ have strongly agreed this fact while $15 \%$ moderately agreed. When we asked about the Government help is sufficient or not, $27 \%$ has been strongly agreed that the Government is providing sufficient help in higher education expansion while $14 \%$ moderately agreed on this fact. When we asked the question about proper monitoring of higher education by UGC, $18 \%$ respondents were agreed strongly while $11 \%$ agreed moderately. Regarding the question, industry need based education is the need of today $12 \%$ were agreed strongly while $24 \%$ were moderately agreed.

Table 4. Existing Higher Education Situation.

\begin{tabular}{|c|c|c|c|c|c|}
\hline Type & $\begin{array}{l}\text { Strongly } \\
\text { Agreed }\end{array}$ & $\begin{array}{l}\text { Moderatel } \\
\text { y agreed }\end{array}$ & Neutral & $\begin{array}{l}\text { Moderatel } \\
\text { y disagreed }\end{array}$ & $\begin{array}{l}\text { Strongly } \\
\text { disagreed }\end{array}$ \\
\hline Excellence in Public Universities(General Education) & $25 \%$ & $22 \%$ & $34 \%$ & $12 \%$ & $7 \%$ \\
\hline Excellence in Public Universities(Technical Education) & $15 \%$ & $21 \%$ & $32 \%$ & $15 \%$ & $17 \%$ \\
\hline Excellence in Private Universities (Both general and technical Education) & $10 \%$ & $22 \%$ & $19 \%$ & $23 \%$ & $26 \%$ \\
\hline Excellence in Medical Education at Public Colleges and BSMMU & $21 \%$ & $32 \%$ & $18 \%$ & $21 \%$ & $8 \%$ \\
\hline Excellence in Medical Education at Private colleges & $9 \%$ & $17 \%$ & $23 \%$ & $39 \%$ & $12 \%$ \\
\hline
\end{tabular}

(Source: Ibid)

Inference: From table 4, while making survey on existing situation of Higher education in Bangladesh we observed that in case of Public universities the presence of General education excellence was strongly agreed by $25 \%$ while moderately agreed by $22 \%$. In the area of Excellence in Technical Education in Public Universities, 15\% strongly agreed that the excellence is followed by general Universities in the Technical education while $21 \%$ agreed moderately in this regard. Regarding the question of excellence in Private universities both general and technical education only $10 \%$ strongly agreed while moderately agreed $22 \%$. Excellence in medical education at colleges and BSMMU 21\% strongly agreed while $32 \%$ moderately agreed. Excellence in medical education at private colleges only $9 \%$ strongly agreed while moderately agreed $17 \%$.

Table 5. Innovations in Higher Education.

\begin{tabular}{|c|c|c|c|c|c|}
\hline Type & $\begin{array}{l}\text { Strongly } \\
\text { Agreed }\end{array}$ & $\begin{array}{l}\text { Moderately } \\
\text { Agreed }\end{array}$ & Neutral & $\begin{array}{l}\text { Moderately } \\
\text { Disagreed }\end{array}$ & $\begin{array}{l}\text { Strongly } \\
\text { Disagreed }\end{array}$ \\
\hline Innovation occurred through use of ICT & $15 \%$ & $31 \%$ & $21 \%$ & $24 \%$ & $9 \%$ \\
\hline $\begin{array}{l}\text { Innovation occurred through use of Interaction, participation and doing things based } \\
\text { modern class room situation }\end{array}$ & $9 \%$ & $28 \%$ & $27 \%$ & $21 \%$ & $15 \%$ \\
\hline $\begin{array}{l}\text { Giving more stress on Concept building rather than memorizing and proper } \\
\text { communication skill development at higher education level }\end{array}$ & $14 \%$ & $22 \%$ & $31 \%$ & $22 \%$ & $11 \%$ \\
\hline Attention is given to develop knowledge and Skills & $12 \%$ & $14 \%$ & $40 \%$ & $27 \%$ & $7 \%$ \\
\hline Test-Teach-Test method & $7 \%$ & $12 \%$ & $31 \%$ & $31 \%$ & $19 \%$ \\
\hline Problem Based learning & $14 \%$ & $14 \%$ & $23 \%$ & $31 \%$ & $18 \%$ \\
\hline Concept mapping & $10 \%$ & $14 \%$ & $28 \%$ & $29 \%$ & $19 \%$ \\
\hline Computer aided Instruction & $16 \%$ & $25 \%$ & $36 \%$ & $15 \%$ & $8 \%$ \\
\hline Teacher act as guided discovery & $11 \%$ & $21 \%$ & $29 \%$ & $24 \%$ & $15 \%$ \\
\hline
\end{tabular}

(Source: ibid)

Inference: We asked some points whether Innovation is made in higher education in Bangladesh or not as reported in 
Table 5 . About $15 \%$ were strongly agreed that innovation is made through the use of ICT while $31 \%$ were moderately agreed. We asked whether Innovation is occurred through the use of Interaction, participation and doing things based on modern class room situation, $9 \%$ people were strongly agreed while $28 \%$ people were moderately agreed. Giving more stress on Concept building rather than memorizing and proper communication skill development at higher education level was strongly supported by $14 \%$ while $22 \%$ moderately supported. About $12 \%$ people were strongly supported on the fact that attention is given to develop knowledge and Skills while $14 \%$ were moderately agreed. Case studies, presentations, assignments, real life experiences, group studies, mobile apps use positively agreed strongly and moderately by $19 \%$ and $38 \%$ respectively. Test-Teach-Test method has been agreed by strongly by $7 \%$ and moderately $12 \%$. In case of Problem Based learning, both strongly and moderately agreed. Concept mapping has been agreed by $10 \%$ strongly and $14 \%$ moderately. Computer aided instruction was agreed by $16 \%$ and $25 \%$ strongly and moderately respectively. Teacher acted as guided discovery was supported by $11 \%$ and $21 \%$ strongly and moderately respectively.

Table 6. Impact of Innovations in Higher Education's in the Socio-Economic Conditions.

\begin{tabular}{|c|c|c|c|c|c|}
\hline Type & $\begin{array}{l}\text { Strongly } \\
\text { Agreed }\end{array}$ & $\begin{array}{l}\text { Moderately } \\
\text { Agreed }\end{array}$ & Neutral & $\begin{array}{l}\text { Moderately } \\
\text { Disagreed }\end{array}$ & $\begin{array}{l}\text { Strongly } \\
\text { Disagreed }\end{array}$ \\
\hline Self employment rises & $16 \%$ & $21 \%$ & $26 \%$ & $19 \%$ & $18 \%$ \\
\hline Social unrest declines & $11 \%$ & $32 \%$ & $24 \%$ & $23 \%$ & $10 \%$ \\
\hline Economic welfare rises & $22 \%$ & $29 \%$ & $32 \%$ & $11 \%$ & $6 \%$ \\
\hline Unemployment declines and purchasing power rises & $24 \%$ & $37 \%$ & $18 \%$ & $12 \%$ & $9 \%$ \\
\hline Gender Inequality declines & $10 \%$ & $24 \%$ & $31 \%$ & $21 \%$ & $14 \%$ \\
\hline
\end{tabular}

(Source: ibid)

Inference: This part is very interesting one since we at last found out the Impact of Innovations in Higher Education's in the Socio-Economic Conditions due to innovations in Higher education as mentioned in table $6.16 \%$ people opined with strong support that Self employment rose by higher education while $21 \%$ people moderately agreed on this fact. About $21 \%$ people opined that Social unrest declined while $32 \%$ people moderately agreed on this fact. About 22\% people were strongly agreed on Economic welfare rise while $29 \%$ people were moderately agreed. About $24 \%$ people were strongly agreed that unemployment declined and purchasing power rose while $37 \%$ people were agreed moderately. $10 \%$ people were strongly agreed on the issue of Gender Inequality declined while $24 \%$ people were moderately agreed.

\section{Special Comments made by Guardians}

- Guardians also argued that in the Entrance Examinations of Public Universities and Private Universities at undergraduate level, question should be set up from the immediate past syllabus. Unforeseen Questions should not be set up in these exams. They opined that due to unforeseen questions, coaching business is getting momentum.

- For general education, another interesting comments made by most of the guardians are that his/her son and daughter's first choice is to get admission into the University of Dhaka.

- Cent percent Guardians' discourages any sort of imposition of direct or indirect tax on higher education.

- Strict measures including closure are being demanded against low quality private universities of Bangladesh.

- Due to political reason some private universities were closed down earlier such as University of Comilla. Guardians requested for providing original certificates to the graduates who duly completed their higher studies. At that time UGC, Bangladesh did not play due role.

- Too much high cost in private medical colleges of Bangladesh must be reduced.

- Zero tolerance of corruption and nepotism in higher education must be ensured by the Govt.

- Coaching business should be stopped for which larger role should be played by the Teachers. They must be more sincere about teaching.

- More emphasis should be given on physical education than the virtual class room.

- Ministry of Primary and Mass education must be separated from the Ministry of Education at Bangladesh. Primary education must be extended up to Class VIII.

- District quota system for job should be abolished which is one of the important factor to stimulate students quality education at higher level.

- Present English teaching system up to twelve classes are faulty.

\section{Concluding Remarks and Implications}

Despite some limitations and problems associated with higher education from 2009 to till now we observe that it supports Psacharopoulos (1994) views. Psacharopoulos opined that higher education is beneficial for the society and individual perspective. Quality assurance is the key factor. Teacher student relationship should be friendlier. Besides basic knowledge, out book knowledge should be raised. Pedagogy in each sort of educational institute in the country requires variety for the complete progress in this area for shaping people knowledgeable and skillful.

Existing English language education system should be replaced by reading more English literatures and creating 
quality English teacher. In the globalised world we have to create core competent human capital for which government is taking lot of steps. However, in the private sector some greedy business magnet thinks that education is source of making super normal profit. Coaching business should be stopped for which not only government but also needs of the guardians' active support are very much required. During the admission test in the undergraduate level, question should set on the basis of previous course curricula for the admission seekers. Otherwise, it will have negative impact on the admission seekers. Decision to give admission test in some public university for only once is a very good decision as each year lot of seats remain vacant when student get admitted to another department/university/medical college.

National university of Bangladesh should monitor its colleges/institutes for proving good quality education which needs further investigation by future researcher. Regarding private medical colleges' education system, a separate research-based study can be undertaken. A separate research work can be done on Outcomes-based teaching and learning system of public and private universities of Bangladesh.

Private University who does not comply with UGC and education ministry's rules and regulations bold steps should be taken to close down. They must be closed down for the greater shake of the students as well as society. Closure down of corrupt and non-compliant rules of UGC of those private universities will help to achieve social welfare as it will make a choice of the fairest and efficient outcome .For example, Presidency University (Bangladesh) doesn't have any govt. appointed Vice chancellor, Pro-Vice Chancellor and Treasurer for long time. Similarly some other universities are facing the same problem. Earlier UGC closed 12 private universities outer campus which is good decision. But strong regulatory measures are needed against other non-compliance universities jointly by UGC, Bangladesh and Ministry of Education, Govt. of Bangladesh. Strong political will is required in this regard and unbiased measure should be taken for the greater interest of the country.

Like Malaysia, China and India, Govt. can give permission to set up outer campuses of World ranking and country ranking higher educational institute in the country. Vision of education has to make the students to become global standard benchmarking within 2021 when the nation will celebrate 50 years of independence. To reach this goal, the country needs to plan to expand research and training facilities and academic programs at higher level. Education is a tool that enriches students' minds with the skills necessary to compete and succeed in a challenging world, and also with the knowledge to maintain peace and justice in the society. Graduating students of the country should turn to very best ambassadors of liberality toward society free from the fetters of colors and castes, of faith, of non-communalism, of gender, and of nationality, as Khalil Gibran says "Generosity is giving more than you can, and pride is taking less than you need." (http://www.goodreads.com/quotes/45514-generosityis-giving-more-than-you-can-and-pride-is). Secular education must get priority along with pursuance for excellence of education. Strategic management of quality education at higher level can be ensured through better utilization of resources and goal oriented vision, mission must be properly implemented so that competitive advantages can be ensured.

Pedagogy at higher educational level should be improved in Bangladesh. Teacher should pursue students for cocurricular activities. Concept building with patriotism is the important factor for students to give future leadership of the country. Appreciate the sense and collision of the tangible can put together into practice in each one presentation pointer would provide innovative thoughts for production and service expansion. More educational grant should be provided to organize research work from external sources for both public and private universities. However, public universities/ Govt. medical colleges and engineering colleges must be gradually self -dependent rather than donation form Govt. to cover their administrative and day to day operational cost.

Those who are involved in providing quality education in this money centric world must possess high ethical and moral values. Quality education will be able to create ample opportunities for knowledge diffusion to build a distinguished record and provide a guideline for the present and future domestic and global scenario. Improved course planning, realistic course objectives, updated delivery methods, appropriate course assessment as per Bloom's Taxonomy benchmarks will ensure outcome-based education and international standards. Entrepreneurial skill and ability will help young learners' for self -employment which is very important.

Accreditation council should be set up for public -private universities and institutes/colleges of National University under Higher Education Quality Enhancement Project (HEQEP). Some global accreditation council is also working in the country. Definitely blending of national and international accreditation council given to an educational institute will give more fruitful results.UGC of Bangladesh is now trying to establish Quality assurance cell in all public and private universities for which World Bank is providing fund through UGC under Quality Assurance unit so that selfassessment program of each dept. of different universities can be done to improve quality education as well further enhancement of education process. Definitely it is a good initiative.

Session Jam of public universities should be eliminated. Otherwise extended time period creates frustration among the students. In this regard Ahmmed(2013) 's observation is quite logical. Government of Bangladesh will have to raise investment on higher education. More spending on physical infrastructure and social infrastructure of the country is required. Govt. expenditure in terms of GDP in the educational sector in Bangladesh should be raised to $6 \%$ as it will elevate the economic productivity through adding value at the global value chain and return on investment will have positive impact on the economy.

Sarkar , Rana and Zitu (2013)s' finding should be considered as an important factor. Investment on higher 
education through greater budgetary allocation should be raised as it will enhance marginal social benefit and have positive impact on economic growth of the country. Mapia nexus between corrupt investor of some private universities, academicians, bureaucrats, students, parents and administrators must be broken down.

Due to the globalization process, economic structure is benefitted through superior higher education. Productivity is increasing due to advancement of globalization process along with continuous learning effect, which is a flow concept. Dynamism in the economic structure occurs when globalization flows with information symmetry which expedites the process of quality higher education and which in turn provides skill, effectiveness, and efficiency which can contribute in economic structure for beneficial of the society as well as nation. Marginal social benefit will be higher than marginal social cost as due to globalization process, spillover effect will occur in the education sector for which international benchmark should be followed in Bangladesh. Low graded foreign trainers'/teachers' should not be brought in Bangladesh as it will rather create confusion for the teachers. In this case work permit should not be given to them from the competent authority. Rather more emphasis should be given to bring high quality educationist from developed nations to train local teachers'/trainers'. Otherwise Malan(2010)'s caution may occur in case of outcomes-based education system. Outcomes-based development of syllabus and student evaluation should be ensured in each higher educational institute.

Marginal social benefit will be higher than marginal social cost if excellence in higher education can be ensured in Bangladesh through effective and efficient utilization of globalization process for which spillover effect ought to be occurred in the educational sector. Schultz(1961) comments should be considered by the policy makers and they should take realistic approach for vertical and horizontal coordination to implement productive utilization on human being through education which has chain effect starting from primary -mid-high school and undergraduate-graduate education in the line of findings of McMahon(1992) .In Bangladesh, outcomes-based teaching and learning must be ensured by the govt. Regular based research and development must be conducted by the higher educational institutes including self-assessment programs of their own organizations. Ministry of Education and UGC of Bangladesh should give permission to the private universities to provide MPhil / PhD and DBA degree where highly qualified academicians, proper physical infrastructure, good library environment, lab facilities and also other facilities for doing research work etc. have been prevailing.

Technology based education must not forget to include humanistic approach as well as ethical approach. International benchmark at the educational sector should be followed in Bangladesh. Bloom's Taxonomy main categories: knowledge, comprehension, application, analysis, synthesis, and evaluation -all the factors ought to be applied to develop its higher educational system of Bangladesh for which restructuring in the higher educational process and implementation of the policies effectively and efficiently is required so that competitive advantage can be attained. Only proper maintenance of excellence and international standard education and research with application will help to improve ranking of Bangladesh's public and private universities in the world ranking. To become upper middle income country by the year 2021, Bangladesh ought to ensure high value added education at all level. To implement National Education Policy 2010 of Bangladesh, Govt. must set up a high powered task force and will have to provide sufficient amount of fund to implement the Education policy under $7^{\text {th }}$ five year plan of the country, which has been started from $1^{\text {st }}$ July 2015.Physical and social infrastructure on educational sector of the country should be developed so that higher education brings economic benefit for the country.

\section{References}

[1] Ahmmed, Md. Mortuza (2013). 'Higher Education in Public Universities in Bangladesh", Journal of Management and Science, Vol. III, No. 2, June .

[2] Alam, Mahmudul (2013). "Private Higher Education in Bangladesh: Issues of Quantity, Quality and Ways ',Forward Keynote paper at The Seminar on Higher Education in Bangladesh December 16 organized by Northern University Bangladesh (NUB), Dhaka.

[3] Bangladesh Bureau of Statistics (2015).

[4] Blundell, Richard, Dearden, Lorraine, Meghir, Costas, and Sianesi, Barbara (1999)."Human Capital Investment: The Returns from Education and Training to the Individual, the Firm and the Economy", Fiscal Studies, Vol. 20, No. 1, pp. 123.

[5] Brown' Phillip and Lauder, Hugh (1996)." Education, globalization and economic development", Journal of Education Policy, Volume 11, Issue 1,pages 1-25.

[6] Clark, Dorie (2013). Reinventing You: Define Your Brand, Imagine Your Future, Harvard Business Review Press. April 9.

[7] Dukkipati, Rao V. (2010). Mechanical Vibrations (English) (Paperback), Narosa Book Distributors Pvt Ltd.

[8] De Meyer, A. (2012). Environmental influences reflections on the globalization of management education., Journal of Management Development, Volume:31,No.4,pp. 336-345

[9] Dukkipati, Rao V. (2010). Mechanical Vibrations (English) (Paperback), Narosa Book Distributors Pvt Ltd.

[10] Hanushek, Eric A., Woessmann, Ludger ( 2007)."The Role of Education Quality for Economic Growth", World Bank, Washington, DC.

https://openknowledge.worldbank.org/handle/10986/7154 License: CC BY 3.0 IGO."

[11] Heckman,James J.(2000)." Policies to foster human capital “, Research in Economics, Volume.54,pp.3-56.

[12] https://en.wikipedia.org/wiki/Kaldor\%E2\%80\%93Hicks_effici ency (access date 15 May,2015) 
[13] http://www.goodreads.com/quotes/45514-generosity-isgiving-more-than-you-can-and-pride-is(access date 15 May,2015)

[14] http://www.learnnc.org/lp/pages/4719,Bloom's Taxonomy by Heather Coffey (access date 11 March,2015).

[15] http://siteresources.worldbank.org/EDUCATION/Resources/2 78200-1121703274255/1439264-

1193249163062/Bangladesh_countrySummary.pdf. (Access date:23 February,2015)

[16] http://www.heqep-ugc.gov.bd/ (Access date:23 February,2015)

[17] http://www.topuniversities.com/university-rankings/asianuniversity-

rankings $/ 2015 \#$ sorting $=$ rank + region $=+$ country $=+$ faculty $=+$ star $\mathrm{s}=$ false + search $=($ accessed on 25 June, 2015$)$

[18] Jonathan (accessed on 17.05.2013)," Is It Time to Reinvent Yourself?',http://advancedlifeskills.com/blog/is-it-time-toreinvent-yourself/

[19] Khaled, Sarwar Md. Saifullah (2014)." Problems and prospects of higher edn in Bangladesh", News Today, May 21

[20] MacMahon,Walter W.(1992).”The contribution of Higher education to R\&D and Productivity growth", Higher Education and Economic Growth, William E. Becker Jr., D.R. Lewis (editor), Springer Science \& Business Media,pp.115116.

[21] Malan, SPT (2000).'The 'new paradigm' of outcomes-based education in perspective", Journal of Family Ecology and Consumer Sciences, Vol 28, 2000, pp.22-28

[22] Mazumder,Qamrul H.(2012).”Quality improvement in higher education in Bangladesh", The Daily Sun, October 22

[23] Monem, Mobasser and Baniamin,Hasan Muhammad (2010)."Higher Education in Bangladesh: Status, Issues and Prospects “,Pakistan Journal of Social Sciences (PJSS),Vol. 30, No. 2 December, pp. 293-305.

[24] Oplatka I. (2014). "Understanding teacher entrepreneurship in the globalized society", Journal of Enterprising Communities: People and Places in the Global Economy, Voulme: 8,No.1,pp. 20-33.
[25] Olssen , Mark and Peters,Michael A.(2005). "Neoliberalism, higher education and the knowledge economy: from the free market to knowledge capitalism", Journal of Education Policy, Volume 20, Issue 3,pp. 313-345.

[26] Psachropoulos, George (1994)." Returns to Investment in Education: A Global Update “, Pergamon -World Development, Vol. 22, No 9, pp. 132-143.

[27] Sarkar, Shakhawat Hossain, Rana , Shohel, Zitu, Rudaba Afrin (2013).' Challenges of Quality Higher Education in Bangladesh: A Study on Public Universities", Journal of Education and Practice, Vol.4, No.8.

[28] Schultz, Theodore W.(1961).'Investment in human capital", The American Economic Review, Vol.51,No.1,March,pp.117.

[29] Siddiqi, Dr. Hafiz G. A.(2014)." Higher education tailored to economic development", The Daily Star,March,12

[30] Wadud, Mushfique (2013). "NU failing to ensure quality education since its inception ",Dhaka Tribune,

http://www.dhakatribune.com/education/2013/aug/02/nufailing-ensure-quality- education-itsinception\#sthash.Immb60kN.dpuf

[31] Weiner, Sharon A, Jackman, Ana W., and Warren, Glen (2014). "America's Missing Link: Educational Reform and Work force Development", Libraries Faculty and Staff Presentations, Paper 54.

http://docs.lib.purdue.edu/lib_fspres/54

[32] Williams, Serena E.(2014). "Education and Economic Development: An Untapped Alliance" ,Honors Theses. Paper 202

[33] World Bank (2014).”Bangladesh: Connecting Minds in Higher Education", http://www.worldbank.org/en/news/feature/2014/03/19/bangla desh-connecting-minds-in-higher-education,March $19 \mathrm{Wu}$ (Access date:23 February,2015)

[34] Wu, Feng-Shang and Haak, Robert (2013)." Innovation Mechanisms and Knowledge Communities for Corporate Central R\&D", Creativity and Innovation Management, Volume 22, Issue 1, Blackwell Publishing Ltd, pp. 37-52, March. 